\title{
EL VAMPIRO DEL DESENCANTO. LOS PARAÍSOS ARTIFICIALES EN LA POESÍA ESPAÑOLA DE LA TRANSICIÓN ${ }^{1}$
}

\author{
Joaquín RUANO \\ Ludwig-Maximilians-Universität München \\ I'll be in my basement room \\ With a needle and a spoon \\ Jagger / Richards «Dead Flowers»
}

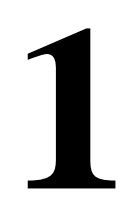

\section{Signos}

a) En una delirante terraza de verano de Madrid, dos jóvenes, de obvia estética punk y sexualidad dudosa, se sientan a una mesa llena de vasos de distintos colores. El chico, con una marcada afectación homosexual, comienza un casi monólogo «Sin dinero, nena, no coche, no chica, no tate, no vicio, no rimmel. Estoy histérica [...] Voy a esnifar un poquito de esmalte... ¡uh!... Toma bonita... qué overdose...» y, tras intercambiar el dicho esmalte, «iQué síndrome! ¡Alcohol por un tubo!... ¡Qué overdose!» (Almodovar, 1982).

b) En un Bilbao gris, marcado por la reconversión industrial, por el paro y por la violencia política, dos jóvenes, Paco y Urku, salen de una academia de preparación de la EGB. Un tercer joven que está con ellos les pide una china fiada, tras lo cual otro estudiante espeta a la pareja protagonista «Qué andas ¿repartiendo drogas, no? ¿Te las da tu padre o qué?». «No», responde Paco, «me las da tu puta madre» (Iglesia, 1983). Ante una trifulca que se prevé inevitable, Urku interviene para salvar la situación. Entonces el estudiante le recrimina que se junte con él. Paco es hijo de un guardia civil, Urku, de un político abertzale. Ambos están unidos, además de por los lazos de la amistad, por la heroína.

c) Tras una agotadora sesión de montaje, el director José Sirgado, vuelve a casa para descansar. Hace un calor agobiante, lo cual, junto con el cansancio, hace que José monte en cólera cuando descubre que Ana, la mujer con la comparte una relación tempestuosa, ha vuelto a su casa. Dispuesto a echarla a la calle, entra en el apartamento para encontrarse a Ana durmiendo. Súbitamente se calma ante la visión angelical. Abre entonces un cajón de la mesilla de noche y, en un primer plano

\footnotetext{
${ }^{1}$ El siguiente artículo es una ampliación y profundización del texto «La aguja en el tintero. La imagen de las drogas en la poesía española de la transición», que publiqué en el libro colectivo Aportes recientes a la literatura y el arte españoles: Estudios de critica narrativa (Recent Developments in Spanish Literature and Art: Studies in Narrative Criticism) (Ruano, 2012).
} 


\section{Tropelías. Revista de Teoría de la Literatura y Literatura Comparada, 23 (2015) \\ El vampiro del desencanto. Los paraísos artificiales en la poesía española de la Transición}

sobrecogedor, se inyecta una dosis de heroína. Descubre entonces, en un paquete postal, una cinta que contiene la grabación en la que Pedro, un extraño muchacho que conoció en un pasado no determinado, le cuenta su descenso a los infiernos en una espiral de destrucción que conjuga el vampirismo, el cine, y la heroína (Gubern et alii, 1995: 391-392). Una espiral de la que el propio no será capaz de sustraerse (Zulueta, 1980).

Los ejemplos podrían repetirse en un número abrumador. La presencia de los estupefacientes en las manifestaciones culturales de la España de la transición democrática son tan reiteradas que no puede ocultarse que reflejan una situación real: la del protagonismo de la búsqueda de la ebriedad en la sociedad española en un momento histórico determinado. Las siguientes líneas tienen por objeto de estudio el tratamiento que de este fenómeno se hace desde el discurso poético. Qué significa que, en un momento determinado la poesía hable del demonio, del tabú, de las drogas. Y, más concretamente, qué visión irreductiblemente única y particular tiene cada uno de los autores que veremos en estas páginas.

\section{Demarcación del escenario}

Se abren, sin embargo varias cuestiones preliminares que es necesario dilucidar antes de entrar en materia. La primera, por seguir un esquema que vaya de lo general a lo particular, concierne al periodo histórico en el que planteamos circunscribirnos. La Transición democrática. Casi todos los autores estudiados dentro del océano de literatura que este tramo de la historia nacional ha producido -desde lo político a lo jurídico, desde lo periodístico a lo cultural- coinciden en que la Transición es un periodo caracterizado por una vaguedad persistente en sus límites cronológicos. Así, como dice Ramón Buckley, «[...] la transición española tiene límites vaporosos, y sobre el principio y el final del proceso hay disparidad de opiniones» (Buckley, 2000: 69).

El mismo Buckley propone como fecha de inicio la de 1968, «por los acontecimientos que se produjeron a nivel mundial» (Buckley, 2000: 69). Otra delimitación, mucho más restringida propone Raúl Modoro quien, a un nivel politológico, circunscribe el proceso transicional a dos años:

Entre diciembre de 1976 y diciembre de 1978, es decir, justamente dos años, se lleva a cabo en España uno de los fenómenos políticos más sorprendentes de nuestra historia contemporánea: la transición pacífica de una larga dictadura a una monarquía democrática. Dos referenda, de 15 de diciembre de 1976 aprobando la Ley para la reforma política, y de 6 de diciembre de 1978, aprobando ya la nueva Constitución [...] culminan [...] el proceso de transición política propiamente dicha (Modoro, 1984: 129).

Desde el punto vista historiográfico, este proceso parece ser algo más amplio. Así, tanto la cronología que elabora Paloma Román Marugán para el volumen La transición democrática española (Tenazos, Cotarelo y Blas: 858-932), como el tomo escrito por Javier Tusell para la Historia de España de la editorial Crítica, proponen como límites temporales el lapso histórico que va desde la muerte del dictador Francisco Franco (noviembre de 1975) hasta la primera victoria electoral del Partido Socialista Obrero Español en las elecciones de octubre de 1982 (Tusell, 2005: 277-334).

Por último, desde le punto de vista de lo que se denomina estudios culturales, Teresa Vilarós propone una datación mucho más amplia que iría desde la muerte del Almirante Carrero Blanco como 
producto de la «Operación Ogro» planeada por la organización ETA el 20 de diciembre de 1973 -la cual eliminaría un obstáculo insalvable hacia la normalización democrática- hasta la entrada en vigor del Tratado de Maastricht el 1 de noviembre de 1993 -con el cual se realizaban las aspiraciones españolas de ser una voz de primer orden en la construcción del marco europeo (cf. Vilarós, 1998)-.

Tenemos pues, un amplio marco que, desde el punto de partida propuesto por Buckley hasta el de cierre propuesto por Vilarós abarca casi treinta años o, lo que es lo mismo, la práctica totalidad del último tercio del siglo XX. Pero si hay disensiones sobre los límites cronológicos, el desacuerdo se extrema en la lectura que de dicho fenómeno transitorial se hace. Así, el espectro abarcaría desde la lectura idílica del ex-vicepresidente del Gobierno, Alfonso Guerra:

Previamente se había venido hablando del desencanto, expresión que resumía el espíritu de ánimo de algunos sectores de la sociedad aparentemente desilusionados por la marcha de ese gran proyecto de revertebración nacional, y en concreto de una juventud que se había desenganchado del tren de la ilusión colectiva $[\ldots]$.

Este desencanto se evapora instantáneamente, tras el 23-F, cuando todo un pueblo arrincona egoísmos y preocupaciones caseras ante el peligro que ha estado a punto de derribar el preciado entramado de las libertades de todos, tan trabajosamente levantado (Modoro, 1984: 20).

Hasta la visión dolorosamente sarcástica de Eduardo Subirats:

En nombre de la estabilidad o paz social se conciertan alianzas políticas y morales con las instituciones, los valores y las representaciones más sombrías del pasado. Se absuelven sus crímenes. Se encubren sus mitos y mentiras. Se silencia su violencia. Se limpian las huellas del dolor pretérito con las esperanzas de un indefinido futuro. Las viejas estrategias de escarnio de las masas son recicladas bajo tecnologías y retóricas nuevas. Y se anuncia lo que ha de venir como el espectáculo maravilloso de un futuro emancipado del pasado: el carnaval de una renovada redención de los signos (Subirats, 2002: 72).

Sin embargo ambas versiones apuntan a un hecho vertebral al fenómeno de la Transición española. El compromiso político, tan fuerte en la década de los sesenta entre los intelectuales, se va disolviendo. La izquierda que ha pasado cuatro largas décadas esperando el fin de una dictadura cruel, sangrienta, se frustra ahora ante la falta de una verdadera ruptura con dicho sistema represor (Buckley, 2000: 73-75). Las fuerzas políticas, además, abandonarán paulatinamente el marxismo como referencia ideológica, dejando las esperanzas de cambio cada vez más vacías, más desencantadas. Se produce, en el imaginario de la intelectualidad, una represión del pasado, una imposibilidad de venganza que torna el sufrimiento anterior en algo fantasmagórico:

Aunque el fin del franquismo señalado por la enfermedad, agonía y muerte de Franco debería haber indicado el inicio de un espacio de reflexión y análisis del pasado inmediato, el cuerpo social español entra por el contrario en un proceso enquistatorio de un pasado que hemos convertido en desecho [...] El momento de la transición es el espacio donde se procesa el olvido, agujero negro que chupa, hace caer y encripta los desechos de nuestro pasado histórico, aquella nuestra historia maloliente que todos nos apresuramos a repudiar y que en gran parte todavía seguimos ocultando (Vilarós, 1998: 12-13).

Queda entonces un vacío, una ausencia de dialéctica ideológica que se constituye en una presencia. Y ante esta presencia el intelectual tiene dos caminos. El primero, el más seguido, es el que lo lleva a un nihilismo postmoderno, una negativa constante a hablar del pasado, que se convierte en el depositario de la máquina represora de la dictadura. «A raíz del reciente pasado político fueron 


\section{Tropelías. Revista de Teoría de la Literatura y Literatura Comparada, 23 (2015) \\ El vampiro del desencanto. Los paraísos artificiales en la poesía española de la Transición}

muchos los que pensaron erróneamente que con la desaparición del franquismo había desaparecido también el fenómeno censorio» (Abellán, 1995: 3). Pero esta nueva censura es mucho menos explícita por cuanto la prohibición está difusa en un estado de libertades. «La intelligentsia instalada en los centros de información y difusión del conocimiento cierra sus filas a una crítica y una revisión necesarias del pasado inmediato» (Subirats, 2002: 85).

El otro camino, mucho menos transitado, también mucho menos acomodaticio y, sobre todo, mucho más pleno de fuerza y de riqueza, es el que pasa, ante el desencanto de la realidad, por la fuga, la búsqueda epistemológica de un éxtasis capaz de negar la mediocridad circundante, capaz de suplir el derrumbe de la superestructura utópica (Vilarós, 1998: 260-261). Nos encontramos, por tanto, con una apuesta por la marginalidad, con una apuesta romántica, heroica, en tanto que se sabe que es una apuesta perdida de antemano y que no puede ser sino perdida porque, como la ruleta rusa, tiene su valor en la posibilidad de la destrucción. La ruptura de todas las trabas morales que han subsistido escondidas desde el franquismo en la sociedad española de la transición como residuos del trauma de una dictadura de cuarenta años se convierte pues en un implacable razonamiento intelectual que escapa de la academia para inscribirse, a ritmo de cicatriz en el cuerpo del escritor. Homosexualidad, promiscuidad, locura y -lo que es el motivo de estudio de estas páginas- la drogadicción que, como la búsqueda del «arrebato» en la película de Zulueta se convierten en un verdadero espacio de ascesis:

La expansión extática de la movida -criada en alcohol, hachís, «poppers», cocaína y caballo- tiene el sentido de conjurar el efecto monumental de la resaca producida por la pérdida del contenido utópico de la superestructura cultural de resistencia a la dictadura. La poesía práctica de la movida, resistente ella misma a la producción de obras, a la producción de ideologías, consiste en hacer coincidir la negación del espíritu con la dosis necesaria del espíritu para que la vida prosiga, para que la juerga pueda renovarse. Al mismo tiempo, en el insomnio plagado de muerte, en la actitud altiva y elegante con la que muchos encararon la noche, puede verse que la juerga no es precisamente el juego fácil que una interpretación superficial de las primeras películas de Pedro Almodóvar, por ejemplo, podría querer suponer. La poesía práctica de la movida es en el fondo un tratamiento de metadona (35).

\section{Demarcación de la sustancia}

Hemos ya delimitado el escenario donde nuestros héroes escenificarán su tragedia. Una tragedia dionisíaca, llena de orgasmos y de resplandores místicos que circulan en las esquinas de una triste sociedad postfranquista. Queda, no obstante por clarificar el tema, el asunto. Hablamos de las drogas. ¿La droga? ¿Las drogas? ¿Los estupefacientes? ¿Los narcóticos? En pocos ámbitos existe un mayor poder de la doxa. Todo el mundo habla de las drogas, aun sin haberlas probado, sin haberlas visto nunca. Los medios de comunicación masivamente transmiten enunciados que la masa repite de una manera mecánica. Pero ¿qué son las drogas?

En su monumental estudio sobre el asunto, Escohotado parte del razonamiento de que las sustancias que entran en nuestro cuerpo por cualquier vía, pueden ser asimiladas por nuestro organismo, convirtiéndose en nuevas células -los alimentos-y las que, no siendo asimiladas, provocan en nosotros reacciones intensas. «Este segundo tipo de cosas comprende las drogas en general, que afectan de modo notable aunque absorbamos cantidades ínfimas, en comparación con las cantidades 
de alimentos ingeridas cada día» (Escohotado, 2005: 1179). Aún más, en este segundo conjunto, están los compuestos que sólo afectan somáticamente (por ejemplo, la penicilina), y «[...] los que afectan no sólo somática sino también sentimentalmente. Estos últimos -que parecieron milagrosos a todas las culturas antiguas- [...] reciben el nombre vulgar de “drogas”» (1179-1180).

Una vez definidas, sólo procede su clasificación y, así, Escohotado distingue tres tipos: los «fármacos de paz» (como morfina, heroína u opio), que «se relaciona[n] con alivio del dolor, el sufrimiento y el desasosiego [...]» (1190); el segundo tipo, los «fármacos de energía» (anfetaminas, crack o cocaína), estarían relacionados «con esa amenidad que el poeta llamaba "no desear los deseos", entre cuyas manifestaciones se encuentran pereza, impotencia y aburrimiento» (1191). Por último, se encontraría la categoría de «fármacos visionarios» que englobaría, entre otros, al hachís, marihuana y LSD y que «proporcionan -o prometen- algún tipo de visión en excursiones a zonas no recorridas del ánimo y la conciencia» (1191). Ahora bien, lo que nos interesa del fenómeno de las drogas es que

junto a la química está el ceremonial, y junto al ceremonial las circunstancias que caracterizan a cada momento de su historia. El uso de drogas depende de lo que química y biológicamente ofrecen, y también de lo que representan como pretextos para minorías y mayorías. Son circunstancias determinadas, pero las pautas de administración dependen enormemente de lo que piensa sobre ellas cada tiempo y lugar. En concreto, las condiciones de acceso a su consumo son al menos tan decisivas como lo consumido (1184).

En efecto, como veíamos al principio, el consumo de drogas se convierte en signo social, como dice Peter Haining «El tomar drogas [...] ha pasado hoy a ser un acto político» (Haining, 1976: 181). Un acto de rebeldía, de ruptura, de deseo de transgresión del sistema moral que soporta un orden político injusto, asfixiante. Las drogas se convierten, pues, en un «complot»:

$[\ldots]$ conviene tener en cuenta dos cosas. Una es que el «complot» se gestó en los círculos más cultos, prácticamente subvencionado por las principales instituciones académicas del mundo. La otra es que no puede divorciarse de una reflexión filosófica sobre las sociedades industriales avanzadas y de un esfuerzo por intervenir en su evolución. Fue un discurso farmacológico, aunque a la vez político y cultural en el más amplio sentido de la palabra. No pretendía hacer política para que las cosas siguiesen más o menos como estaban, cambiando a unos gobernantes por otros, sino en el sentido de lo que Nietzsche llamara Gran Política (Grosse Politik) [...] El apoyo químico que ofrecía no era por eso un fin en sí mismo, sino un escalón para retener libertades civiles y un acceso a formas de goce perseguidas o amenazadas por el desarrollo de la civilización (Escohotado, 2005: 792-793).

\section{El tiempo de los asesinos}

No es nueva, sin embargo, esta relación del poeta con las drogas. Ciñéndonos al marco de la cultura occidental, debemos estar de acuerdo con Octavio Paz cuando afirma que el uso de los estupefacientes por el poeta tiene un momento muy preciso:

No deja de ser turbador que la desaparición de las potencias divinas coincida con la aparición de las drogas como donadoras de la visión poética. El demonio familiar, la musa o el espíritu divino ceden el sitio al láudano, al opio, al hachís y, más recientemente, a dos drogas mexicanas: el peyote (mezcalina) y los hongos alucinógenos. La Antigüedad conoció muchas drogas y las utilizó con fines de contemplación, revelación y éxtasis. [...] La diferencia es la siguiente: para los creyentes estas prácticas constituyen un rito; para algunos poetas modernos y para muchos investigadores, una experiencia (Paz, 2000: 224-225). 


\section{Tropelías. Revista de Teoría de la Literatura y Literatura Comparada, 23 (2015) \\ El vampiro del desencanto. Los paraísos artificiales en la poesía española de la Transición}

Así pues, debemos encontrar el origen de esta tradición que entronca las drogas con la poesía en el Romanticismo inglés, concretamente en la pareja Coleridge - de Quincey ${ }^{2}$. Será precisamente éste último quien tenga una transcendencia mayor (Haining, 1976: 35), puesto que, como señala Mario Praz, da a su experiencia de la droga un tratamiento analítico que trasciende el mero experimento poético para convertirse en método de trabajo:

La pretendida afinidad del poeta con un estado anormal de frenesí o de sueño, lugar común de la tradición occidental desde la época clásica, no podía no dar lugar a alguna receta de medios para producir artificialmente esta condición privilegiada [...] así, en el periodo romántico, cuando el sueño, aquella misteriosa cámara oscura (como De Quincey llamó a la mente en su condición de sueño), fue exaltado como fuente de poesía o, directamente, forma de arte en sí mismo, se creyó descubrir en el opio un «método de trabajo» apto para llevar el sueño a los umbrales de la poesía [...].

El descubrimiento del opio como atajo para alcanzar la vía del Parnaso tiene una fecha: 1822, año de la publicación de las Confesiones de un inglés comedor de opio (Praz, 1988: 421).

En efecto, encontramos en de Quincey, al menos parcialmente, la justificación de la toma de estupefacientes como un método de mejorar las capacidades intelectuales:

Now, then, I was happy: I now took only one thousand drops of laudanum per day -and what was that? A latter spring had come to close up the season of my youth. My brain performed its functions as healthily as ever before. I read Kant again; and again I understood him, or fancied that I did (Quincey, 1930: 201).

Sin embargo, bien que el iniciador, el gran fundador de la tradición de las drogas como método de trabajo literario no es otro que Charles Baudelaire. Y es que si, antes que él, Thomas de Quincey y su adorado Edgar Allan Poe ya habían probado ese camino (Baudelaire, 1961: 127 y 131), mientras que los anteriores deploraban la caída que suponía rebajarse a la adicción, o incluso a la toma de narcóticos, Baudelaire tiene la fuerza de, aun reconociendo el inmenso riesgo que existe en el uso de estos paraísos artificiales, reconocer también que la ebriedad supone un «espejo mágico» donde el hombre descubre reflejos de sí insospechados en la sobriedad:

C'est pourquoi je préfère considérer cette condition anormale de l'esprit comme une véritable grâce, comme un miroir magique où l'homme est invité à se voir en beau, c'est-à-dire tel qu'il devrait être ; une espèce d'excitation angélique, un rappel à l'ordre sous une forme complimenteuse (100).

Y es que en el vino, léase la ebriedad, el hombre adquiere una personalidad nueva, una personalidad que no es exactamente la suya propia ni la del propio narcótico, sino una tercera persona, híbrida, que se produce de la comunión de ambos. A esta personalidad se llega mediante el exceso que hace olvidar al hombre su propio ser si bien, no está de más de más recordarlo, el propio Baudelaire advierte que dicho exceso tiene efectos perjudiciales sobre el que se somete a él. En cualquier caso, locura o efectos de la ebriedad, el artista moderno los afronta a cualquier precio, sin importarle pagar el precio que sea ente la posibilidad de acceder, de elevarse, al infinito:

L'idée m'est venue de parler du vin et du haschish dans le même article, parce qu'en effet il y a en eux quelque chose de commun: le développement poétique excessif de l'homme. Le goût frénétique de

\footnotetext{
${ }^{2}$ Cf. Paz (2000), así como Haining (1976: 17) y Escohotado (2005: 417 y ss.).
} 
l'homme pour toutes les substances, saines ou dangereuses, qui exaltent sa personnalité, témoigne de sa grandeur. Il aspire toujours à réchauffer ses espérances et à s'élever vers l'infini (92).

Es en ese momento, cuando el artista narcotizado ya no es una persona, ni tampoco es la droga, sino una tercera persona, cuando se puede soportar la violencia de la pérdida de los dioses, puesto que el narcótico nos da la ilusión de ser un dios:

Personne ne s'étonnera qu'une pensée finale, suprême, jaillisse du cerveau du rêveur : «Je suis devenu Dieu!» qu'un cri sauvage, ardent, s'élance de sa poitrine avec une énergie telle, une telle puissance de projection, que, une vertu efficace, ce cri culbuterait les anges disséminés dans les chemins du ciel: «Je suis un Dieu!» Mais cet ouragan d'orgueil se transforme en une température de béatitude calme, muette, reposée, et l'universalité des êtres se présente colorée et comme illuminée par une aurore sulfureuse. Si par hasard un vague souvenir se glisse dans l'âme de ce bienheureux: N'y aurait-il pas un autre Dieu? croyez qu'il se redressera devant celui-là, qu'il discutera ses volontés et qu'il l'affrontera sans terreur. Quel est le philosophe français qui, pour railler les doctrines allemandes modernes, disait : «Je suis un dieu que a mal dîné?» Cette ironie ne mordrait pas sur un esprit enlevé par le haschish; il répondrait tranquillement: «Il est possible que j'aie mal dîné, mais je suis un Dieu» (141).

Pero si Baudelaire es el gran teórico del matrimonio entre la actividad poética y la droga, Rimbaud ayuda a la construcción de esta imagen del escritor (y de la escritura) aportando, en primer lugar, una aplicación directa de escritura bajo el influjo de la droga. El poeta, nos dice el joven escritor, «se fait voyant par un long, immense et raisonné dérèglement de tous les sens» (Rimbaud, 1972: 251). Pero este desajuste de los sentidos tiene una contrapartida: el poeta vidente, al sufrir en sus carnes el desarreglo de los sentidos, se hace poeta no sólo de la luz, sino también de los infiernos, el poeta es vidente de la lucha y la subversión del mundo burgués (Murphy, 1990: 274-275), y para ello buscará lo monstruoso. Y es para conocer lo monstruoso, para devenir lo monstruoso es necesario, por tanto, «encrapularse», forjar el yo en las más bajas pasiones, hacer la revolución de los parias, como en el poema de Rimbaud «Le Forgeron»:

L'Homme par la fenêtre ouverte, montre tout

Au roi pâle et suant qui chancelle debout,

Malade à regarder cela!

«C'est la crapule,

Sire. Ça aux murs, ça pullule :

-Puisqu'ils ne mangent pas, Sire, ce sont des gueux» (Rimbaud, 1995: 214).

Sin buscarse, o buscándose, la voz poética se encuentra narrando ese universo que se está creando a partir de la droga, universo formado por imágenes que se van juntando fantasmáticamente, para crear un aura, un conjunto de imágenes del escritor en la droga. Un último ejemplo decisivo para los poetas que estudiaremos a continuación, es el de la escritura -la figura- del escritor William S. Burroughs, imagen decisiva en la segunda mitad del Siglo XX. Burroughs lleva un paso más allá las experiencias de Rimbaud, convirtiéndose la droga en centro de su escritura. Una obra que atestigua el encrapulamiento que produce el vampiro de la droga: la adicción. Como dice Escohotado:

Si antes de 1920 puede afirmarse que el 99 por 100 de quienes creen en dope friends son personas que no usan asiduamente opiáceos o cocaína, siendo por eso mismo un típico caso de «creencia pasiva», desde mediados de los cincuenta apenas hay consumidores de esas drogas que no enarbolen como credo y bandera, haciendo gala de una «creencia activa» en el cliché. El manifiesto gremial, lógicamente anterior a la difusión 


\section{Tropelías. Revista de Teoría de la Literatura y Literatura Comparada, 23 (2015) \\ El vampiro del desencanto. Los paraísos artificiales en la poesía española de la Transición \\ de la actitud, se localiza en la obra de W. Burroughs, presentando ya desde el comienzo una puntual inversión con respecto al heroinómano de principios de siglo (Escohotado, 2005: 736).} 451

En efecto, Burroughs es el vidente de las drogas, las cuales presentan en la obra de Burroughs una estructura piramidal, en cuya cumbre encontramos la heroína como droga de drogas, como máxima expresión, no sólo de visión sino de autodestrucción extremas. Estructura, veremos, determinante en la poesía que se hace en la transición desde un grupo de autores, que configuran la droga como uno de los elementos de transgresión, y de subversión social que el fenómeno del desencanto ha dejado en ellos, una estética que va más allá del hedonismo -y nihilismo- de la movida madrileña, si bien en algunos casos, partirá de él.

\section{Les poètes maudits}

Uno de los poetas que surgen precisamente de la respuesta hedonista al desencanto es el madrileño Eduardo Haro Ibars (1948-1988). En pocos poetas como en Haro Ibars encontramos un canto tan persistente del mundo de la noche, de un mundo eléctrico, de búsqueda desesperada del placer y, por supuesto, de la heroína que se esconde tras el lenguaje surrealista de sus versos, o que se muestra tan explicita, como en la dedicatoria de «Reina de Chutas» ${ }^{3}$ : «Para todos los yonquis, víctimas de un sistema social asesino. Para que muera aunque sea bella. La Reina de Chutas. Y todos sus sirvientes» (Haro Ibars, 2001: 217).

En el texto, la heroína se presenta como evidente reina de las drogas. Esta imagen, que ya hemos visto que origina en el discurso literario Burroughs, toma su mayor apogeo en el tramo final de los 70 y durante una gran parte de los años 80: las otras drogas son una diversión, pero sin embargo la heroína te absorbe, te vampiriza, te domina e invariablemente te destruye. La heroína supone una verdadera destrucción del orden social, tomando a cambio la vida del revolucionario:

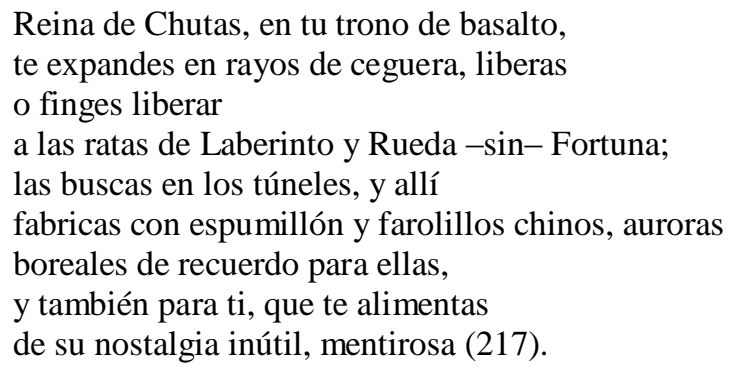

No deja de ser sorprendente la manera en que, naciendo como hemos visto la introducción de las drogas en la literatura occidental en el periodo Romántico, el arquetipo de dicho periodo se reproduce incesantemente doscientos años después: la imagen de un poeta eternamente adolescente, atormentado por ideales imposibles que, ante la afirmación absoluta imposible, opta por la negación absoluta:

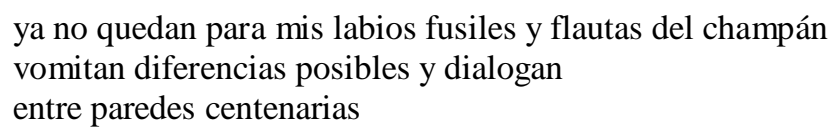

\footnotetext{
${ }^{3}$ «Chutarse» es, según el Diccionario de la RAE «inyectarse droga».
} 
la abadía está en ruinas pero bajo su suelo un muchacho muy pálido espera que atardezca (49).

La palidez, como en el Arrebato de Zulueta, presenta la revisión de otro mito que tiene un punto de inflexión en el periodo romántico: el vampiro. El yonki es un vampiro, un elegante vampiro que ha quedado atrapado en la no-vida y asiste a la tragedia de que el mundo ha devenido un mundo que no es el suyo:

Yo sé que no moriste sin ver

Los más bellos cristales y fuiste condiscípulo

De aquellos elegantes vampiros que leían

Novelas de aventuras

Y que después surgieron abogados o médicos

De sus pozos cuando sonó el hierro candente cuando el tren

Llamó a sus ventanas (44)

Pero el yonki es a la vez vampiro y vampirizado, su vida se consume mediante los colmillos que ahora son agujas, su sed eterna de sangre es sed eterna de droga, del éxtasis que hace al poeta acceder a los paraísos artificiales, y la vida del poeta se convierte en la no vida del vampiro. No es, por tanto, de extrañar que la voz poética de los siguientes versos se disfracen con el nombre de Jonathan Harker:

De un viaje permanece solo el suspiro

Y quien no ha muerto

Con su caballo gris desprende esquirlas

Produce profecías y se eclipsa -por la ladera en tanto

Se arrastran cintas verdes y milagros (63). ${ }^{4}$

Los mismos personajes, pero distinto escenario. Al igual que Drácula deja un mundo feudal y campesino para encontrarse con los albores de la civilización industrial, pero los poetas tocados por la adicción, el vampiro yonki de la transición, experimentan el cambio del secular orden franquista a la democracia. Pero estos nuevos vampiros no añoran su viejo orden, sino que, con desenfreno, se lanzan a la nueva definición del escenario nocturno: un nuevo escenario urbano, eléctrico, pleno de bares y de una diversión que sólo puede ser eternamente efímera:

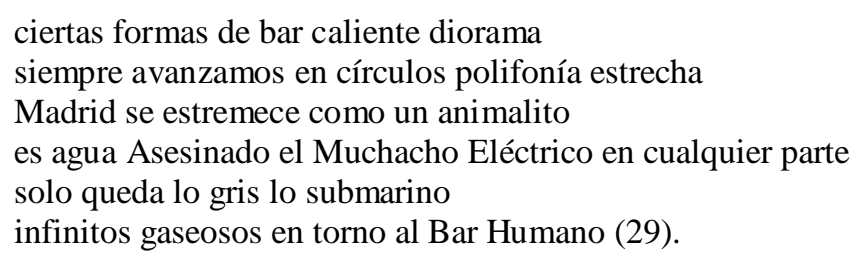

La noche se presenta como un espacio donde la diversión es negación, negación de normas morales burguesas, donde la transgresión quiere ser fiesta dionisíaca de desenfreno y de música rock. «La música rock y el uso de la droga tienen la virtud de crear una subcultura con un lenguaje, unas costumbres y unas creencias propias», dice Peter Haining (1976: 320). La transición española supone la entrada de España en la Postmodernidad, y se inaugura con una nueva vanguardia que utiliza el

${ }^{4}$ «Caballo» es, según el Diccionario de la RAE, una forma coloquial de referirse a la heroína. 
cliché como forma de transgresión del tiempo presente. Se inaugura, por tanto, una política de situación en la que la situación, lo permanentemente efímero, se hace todo. Como en los versos de otro de los actores de la movida madrileña, Leopoldo María Panero:

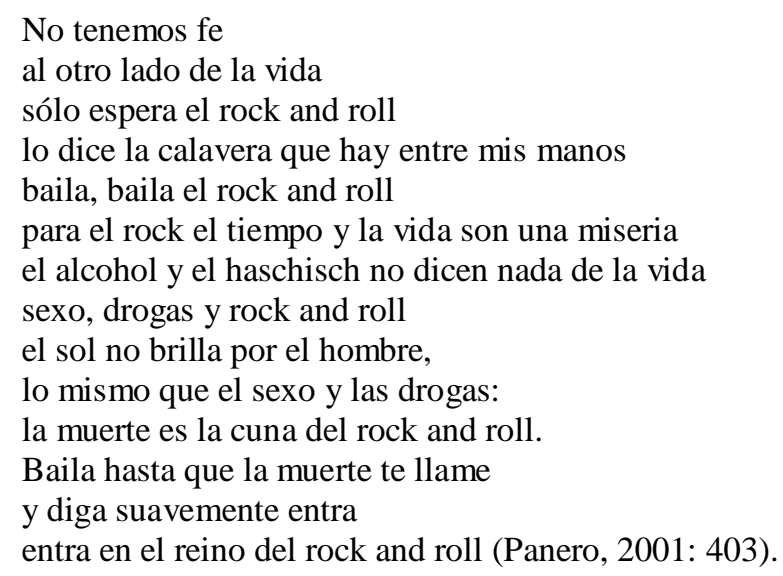

Poeta al que quizá han perjudicado sus estridentes declaraciones públicas -su deseo d'épater le bourgeois - lo cierto es que la obra de Panero sobrepasa esa cortina mediática, mostrando una obra erigida sobre los pilares de una biblioteca de oscuridad, sufrimiento, y transgresión. Su saber muestra los rincones más oscuros del saber oficial, instituyéndose como una contracultura. De este modo, es inevitable que el mundo de los narcóticos no impregne ampliamente la obra de Panero. Ya en su primer libro, Así se fundó Carnaby Street, encontramos varias referencias al THC, el principio activo del cannabis que la marihuana comparte con el hachís:

Y aquella tarde que fui al ballet ruso. Mi padre me llevaba de la mano. Su risa se parecía a la muerte ¿O era él quien se parecía a la muerte? Las cenizas de la marihuana son blancas. Esto, claro, no se aprende en la escuela (38).

Es el caso también de «La canción de amor del traficante de marihuana», donde la droga aparece como un paliativo de lo insoportable de la vida:

Y para qué morir si en los barrios adonde

el carmín sustituye a la sangre

nos dan por 125 ptas. algo que según dicen es un sucedáneo de la miel

aunque a veces contiene pestañas ahogadas en ella

que hay que separar cuidadosamente antes de usarla [...]

y en el espacio de dos horas no oír más que el ruido que ella misma produce (70).

También el alcohol aparece frecuentemente en su obra poética, si bien éste suele tener un carácter mucho más destructivo. En «La canción del croupier del Mississippi», el alcohol, junto con el juego y el tabaco, aparece como un elemento dentro de un delimitado programa de autodestrucción:

[...] No hay,

no existe en nadie esa cosa que llaman corazón

sino quizá en el alcohol, en esa

sangre que yo bebo y que es la sangre de Cristo,

la única sangre en este mundo que no existe

que es como el Mal programado, o 
como fábrica de vida o un sastre que ha olvidado quien es y sigue viviendo, o quizá el reloj y las horas pasan (219-220).

Es el alcohol por tanto signo de destrucción porque, como decía Baudelaire, su efecto nos hace olvidarnos de la vida, de lo inhumano, del dolor, y esto nos vampiriza, haciéndonos caer en el pozo de destrucción y miseria que conlleva el exceso:

Temo las borracheras del boxeador sonado, que se cree san Pedro. El tráfico de alcohol aquí es incesante. Mi belleza, con la que han acabado el alcohol y los manicomios, es tan sólo un incentivo para la muerte (375).

También aparecen en la iconografía de las drogas que se nos presenta en la obra de Panero otras drogas, como la amapola, la flor de la que se produce el opio:

La Amapola es la Flor que nace de la caridad del Diablo, Para con los Sedientos, para con aquellos que han de elegir Entre la Amapola o el Hielo, o la lejana visión del Salón de los Espejos. Mas la Amapola se deshace con inocente crueldad en las manos de los Sedientos (72).

O como la morfina, droga decadentista por excelencia que aparece ya insinuada en «20.000 leguas de viaje submarino», texto perteneciente a su primer libro:

Como hilo a aguja que casi no se siente como débil cristal herido por el fuego como un lago en que es dulce sumergirse oh esta paz que de pronto cruza mis dientes este abrazo de las profundidades (68).

Mucho más explicita aparece esta droga en «Condesa Morfina»:

[...] me cogió de la mano poderosa e impotente como un niño llamándome en la sombra, con voz escasa con voz escasa y tus harapos blancos, llamándome en la sombra, hermosísima dama (121).

Y tampoco podemos olvidar al LSD, droga de preferencia en la época de juventud de Panero:
Alicia en el llano sonaba
Con rojo teji · ó su baba
Un viejo en la cruz · ágata
En lámpara viejo ojo y cruz
Esquizofrénico niño mas Un viejo en el yano [sic] hablaba (128).

\section{LSD limerick}

La obra de Panero es especialmente interesante para nuestro estudio, puesto que, en su acumulación enciclopédica, el saber contracultural de Panero se construye a manera de estratos, como acumulación de experiencias que, gracias a su estratificación, permiten ser objeto de datación. Así, podemos encontrar que la obra de Panero refleja fielmente la transformación de los hábitos de consumición de drogas. De la marihuana y el LSD de los últimos años del franquismo en los que 


\title{
Tropelías. Revista de Teoría de la Literatura y Literatura Comparada, 23 (2015)
}

El vampiro del desencanto. Los paraísos artificiales en la poesía española de la Transición

escribe sus primeros libros, a la coronación de la heroína como reina vampiro en los años 80 y primeros 90. Llegará Panero, en esta veneración destructiva, a dedicarle en 1992 todo un libro de poemas, Heroína y otros poemas. Un canto enamorado a la droga como medio de hacerse vidente:

\author{
De mujeres y de saliva \\ sólo está hecha la vida: \\ la heroína es más que el ser \\ y algo que la vida excede (413).
}

Quizá el efecto más observable es que, bajo el efecto de la heroína, el verso se vuelve tranquilo, hay tiempo de calibrar, las imágenes. La heroína narrada desde la heroína, y no desde la abstinencia, otorga una suerte de placidez extática, donde las imágenes se vuelven símbolos, y los símbolos, lenguaje:
La aguja dibuja lenta
algún ciervo entre mis venas
cuando el veneno entra en sangre
mi cerebro es una rosa (p. 415).

Se forma el fetiche, ya no es la sustancia en sí, sino la sublimación de la jeringuilla, colmillo que vampiriza, objeto que penetra y que, con el tiempo, se convierte en un elemento al menos tan importante como la dosis 5 . Una de las imágenes más comunes sobre la jeringuilla es el cristal, que atraviesa la piel para introducir luz. Un diamante a través del cual se observa otra perspectiva de la realidad.

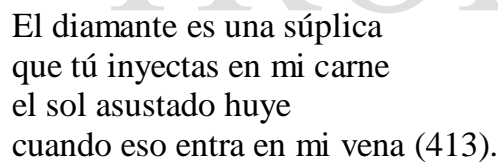

Unos años antes, también el salmantino Aníbal Núñez (1944-1987), en su última producción poética, utilizara esta imagen cristalina para el acto copular de inyectarse la heroína. Así, su Cristal de Lorena, del que nos dice una nota anónima inserta en la primera edición: «A. N., reconoció en esta metáfora una cifra de su trabajo propio y decidió hacerla funcionar en un escenario más complejo cuyos verdaderos límites ni queremos ni podemos dar cuenta» (Núñez, 1995: 384). La heroína se vuelve una vez más deslumbramiento, éxtasis, cristal mágico que lacera en un ascético y duro camino de perfección:

\footnotetext{
Lo que deslumbra hiere y sin embargo

Es la herida quien presta su sangre y su dolor

A la visión más alta: deja huellas

El paisaje exaltado

El imborrable cerco de un orbe suplicante

Que no se sabe si no es visto

Y no se ve si no se sabe (385).
}

\footnotetext{
${ }^{5}$ Sobre el fetichismo creado en torno a la jeringuilla, cf. Escohotado (2005: 1214 y ss.).
} 
Se produce por tanto en la lírica final de Aníbal Núñez una interesantísima identificación de la droga con la poesía, análoga a la que se produce en Arrebato de Zulueta, donde la práctica artística toma los mismos hábitos de éxtasis y abstinencia. Es ya la poesía la que vampiriza, la que roba la vida al poeta y, como la droga, tiene dos caras: Así, junto a las luces del Cristal de Lorena se esconde la maldición del vidente, el «Cristal de Bohemia»-«falso topacio o cuarzo teñido de su color» (388)-:

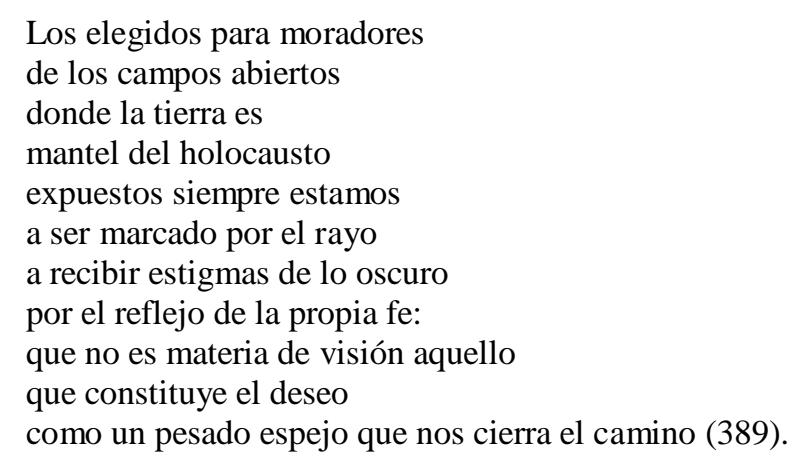

La poesía, por tanto, se convierte ya no sólo en personificación de la droga, sino en droga misma, que impone tiránicamente una adicción con la que no responde sino con varios falsos cristales. Una primavera soluble (como la heroína), hacia cuya luz el poeta no puede evitar marchar, aun a costa de su destrucción:

\footnotetext{
PRÓLOGO

(Porvenir devorado por un incendio)

Débil en la tarea que se impuso

la imperfección de que debió servirse

hace que deploremos vivamente

el deterioro de su compañía (369).
}

Se establece así, un triángulo fatal entre la droga, la poesía, y la vida, puesto que, como estamos viendo, la vida se une indisolublemente a esos dos actos destructivos, siendo la vida el lienzo sobre el que trazan las imágenes, las vivencias, las heridas, de tal modo que ya no es que la poesía narre la vida, sino que la vida se ha convertido en acto poético, artístico, siendo el cuerpo las páginas que la heroína destruye con su trazo punzante:

\footnotetext{
Tallo trunco de lirio

el aire pudo acariciarlo

el filo puede deslumbrarlo

el Sol podrá beber en él.
}

Despojo melodioso de la soluble primavera se lo lleve río abajo la crecida de llanto (370).

Hacer de la vida una obra de arte, una obra que sangre, que salga de los libros para convertirse en texto viviente que niega el conjunto de normas de comportamiento -el conjunto de normas morales-, un texto que, ante el profundo desagrado por la realidad, niega ésta con un fervor casi místico y prefiere arrojarse de brazos abiertos a la destrucción de los paraísos artificiales. Quizá el ejemplo 
más fulgurante de este nuevo mito de Ícaro sea el injustamente desconocido poeta malagueño Fernando Merlo (1952-1981). Fulgurante es un resplandor de gran intensidad que dura apenas un instante, y así queda descrita tanto la existencia vital como poética, ambas ellas, por ser dos facetas de lo mismo, igualmente impregnadas por la búsqueda del exceso, del límite, de la transgresión infinita. La figura de Fernando Merlo se instituye así en nuestras letras como una nueva imagen del poeta romántico, el poeta eternamente joven en la muerte ${ }^{6}$. En su obra, concebida al baudelairiano estilo de libro-vida (Merlo, 1992: 163), los versos no narran otra cosa sino los caminos paralelos de la búsqueda de lo extremo en la vida y en la escritura:

Escatófago es el proceso de una destrucción, siendo a la vez el proceso de la autodepuración poética de su autor ¿Hasta qué punto fue consciente Fernando Merlo de que en el proceso de estilización a que durante años estuvo sometiendo a su obra le iba la vida? También podemos formular esta pregunta al revés ¿Fue esta depuración producto del proceso de autodestrucción al que Fernando se entregó en los últimos diez años de su vida?

Nada que escribiera Fernando Merlo no había sido producto de una vivencia intensa y extensa (162).

En efecto, en Fernando Merlo mejor que en los autores anteriores podemos ver la poética llevada a sus máximas consecuencias, puesto que en este caso se encuentra condensado en una sola, un solo discurso que se apaga tras refulgir tan sólo un instante. Pero también porque al tratarse precisamente de un proceso, la obra de Fernando Merlo estructura todos los rasgos, todas las imágenes, de la droga y la poesía. El proceso dicta la historia de destrucción, ejemplificando todas las características anteriormente descritas, como el ambiente urbano de esta poesía. Unas calles vistas desde el desencanto:

$$
\begin{aligned}
& \text { [...] y es la porquería de } \\
& \text { nuevo en la calle invadiendo los } \\
& \text { tejidos al caminante urbano solo } \\
& \text { que a él ya la porquería lo infesta } \\
& \text { lo infestaban soñoliento hasta las } \\
& \text { aceras y las cejas alrededor se } \\
& \text { dilapidaba el asunto se escribe } \\
& \text { se pinta se abusa de la anécdota } \\
& \text { se la convierte en dibujo interro- } \\
& \text { gante }
\end{aligned}
$$

sistematiza la locura dijo cansado mi cerebro (58)

Una realidad triste, gris, llena de porquería. Sin posibilidad de desarrollo en dicha sociedad, llegado el desencanto de la revolución imposible el artista busca escapar de dicha sociedad ineludible. Surge entonces el deseo de olvidar, de ver más allá, y, como en Rimbaud, el proceso debe comenzar por el encrapulamiento, por romper con todo lo que la sociedad tardofranquista prohibe, y todo lo que la sociedad protodemocrática no se atreve a aceptar, como por ejemplo, y sobre todo, la homosexualidad:

\footnotetext{
${ }^{6}$ Imagen, sin duda, enriquecida de nuevo por la importancia que el rock tiene para nuestros autores. En efecto, la mitología del rock lleva al límite el ejemplo de Rimbaud, con el tópico del «Die young, stay pretty». Janis Joplin y Jimi Hendrix mueren en 1970, Jim Morrison en 1971, los tres tenían 27 años. Fernando Merlo muere a los 29.
} 
Cogerlo por la punta y chuparle el tronco ¡Oh amor mío! Si me lo hubieses no habría tragado porque la besé aún una gota de perla y mi amigo guardará su pistola y más allá crepita y se consume como un pito delicioso obliga entrando a las alcantarillas del encéfalo (el cráneo no deja un resquicio por donde huya) converge la araña que por el corazón se encuentra hubiese estrangulado la roja humedad al latir las emociones abajo esa delicada altitud siendo víscera padre (108). ${ }^{7}$

La transgresión, por definición, no conoce límites. Tras la orgía, el vacío vital sigue persistiendo, y es entonces cuando se recurre a las drogas, como escape, pero también como método de trabajo:

sobre un lado darte las desgracias querido querida los cuadernos débiles amarga marihuana para humedecer los labios (84).

Un proceso de destrucción que termina en la reina vampiro, la heroína:

la semana, dos veces a la semana con los tiempos fríos, una vez, dos veces; a cansar empieza la jeringa y la cantidad exacta de oscilante orgasmo (46).

Y a partir de aquí la destrucción asegurada, la tensión de la abstinencia, de la búsqueda intensiva y desesperada de nueva dosis, a la fetichización de la aguja, la espera certera de la muerte. Y es así, con este panorama sombrío, como acaba su obra poética:

\footnotetext{
A MIS VENAS

Estos cauces que ves amoratados y de amarillo cieno revestidos eran la flor azul de los sentidos que hoy descubre sus pétalos ajados

Besos verdes de aguja en todos lados hieren la trabazón de los tejidos y denuncian los brazos resentidos la enigmática piel de los drogados

Las que llevaban vida y alimento son tibias cobras de veneno breve blanco caballo con la sien de nieve

Trotando corazón y pensamiento que por las aguas de la sangre vierte con rápido caudal la lenta muerte (p. 126).
}

\footnotetext{
${ }^{7}$ No poca materia hay para tratar con respecto a la transgresión y la homosexualidad en la cultura. Como una primera aproximación cf. Pérez-Sánchez (2007: passim).
} 


\section{Tropelías. Revista de Teoría de la Literatura y Literatura Comparada, 23 (2015) \\ El vampiro del desencanto. Los paraísos artificiales en la poesía española de la Transición}

Estremecedoramente profética, la escritura de Fernando Merlo cierra el ciclo que sólo con la muerte podía concluir. La obra esta completa, la transgresión realizada, el proceso de demolición conseguido. Pero las últimas líneas de Fernando Merlo trascienden lo meramente literario para alcanzar que la vida sea vivida como una obra de arte en sí misma la vida, aun a costa de convertirse en una espiral aterradora de descenso a los infiernos. Así, las últimas líneas de Fernando Merlo no son escritas sobre ninguna página:

Aquella tarde, 12 de octubre de 1981, su hermana Gloria llama a la puerta y nadie responde, da la vuelta y entra por detrás. Se encuentra a Fernando sentado tras la barra (ahora mostrador), la cabeza sobre el pecho, la jeringuilla colgando del brazo. Intentan recuperarlo, pero es inútil (160).

\section{La maldición del ángel caído: el anarquista derrotado}

Las últimas líneas de la experiencia de las drogas en la poesía de la transición. Se escriben, con una jeringuilla, en los cuerpos; sus textos no son otros que las propias biografías. Las últimas líneas de Haro Ibars, de Panero, de Núñez y de Merlo nos hablan de manicomios, de SIDA, de sobredosis: de destrucción en definitiva. Esas últimas líneas vuelven a narrar la historia de Ícaro, la destrucción del alma romántica, el peligro de la poesía como vampiro, que convierte al poeta en adicto al éxtasis original -y nunca más recuperado en su totalidad- de los paraísos artificiales. Y sin embargo, más allá de lo anecdótico, la experiencia de estos poetas se convierte en expresión política, en texto ideológico, es decir, en escape (léase rechazo) del poder:

Una escritura que salta fuera de las autoridades un gesto o «movida» paralelo a aquél generado desde la locura, desde las relaciones sexuales entre varones y desde la heroína presentes en los escritos [...], los textos plumíferos e infectados de la transición abrazan un tipo activo de éxtasis a través de la epistemología del místico, del heroinómano, del esquizofrénico o del «pervertido». Un cuerpo infectado fragmentado, compuesto, que puede alternativa o simultáneamente conformarse como entendido o yonqui, yonqui o «esquizofrénico» o cualquier otra combinación que queramos construir (Vilarós, 1998: 255-256).

$\mathrm{Y}$ es que, como apunta Escohotado, «[...] en un mundo donde la esfera cotidiana se encuentra cada vez más teledirigida, cualquier cambio en la vida cotidiana constituye potencialmente una revolución» (2005: 17). Anarquistas derrotados, que en su derrota hacen parábola del terrible sistema de poder. Bohemia maldita, tribu profética o, como dice Benjamin parafraseando a Marx, «conspirateur de profession»(Benjamin, 2001: 25): Anarquistas derrotados, ideando balbuceantes revoluciones imposibles y revueltas etéreas que no pueden cumplirse sino en el texto imposible de sus trágicas biografías,

Con que mano entonces escribir hermosos versos

Con que la cerilla que se apaga el precio demasiado alto para volver a encenderse (Merlo, 1992: 118).

\section{Bibliografía citada}

Abellán, M. L. (1995): «Algunos determinismos sociales del franquismo y la transición», en BONADDIO, F. y HARRIS, D., eds., Siete ensayos sobre cultura posfranquista. Aberdeen, University of Aberdeen, pp. 2-9. 
Almodóvar, P. (1982): Laberinto de Pasiones. España, Alphaville S. A.

BAUDELAIRE, C. (1961): Les paradis artificiels. París, Gallimard.

Benjamin, W. (2001): Iluminaciones II: Poesía y Capitalismo. Madrid, Taurus.

BuCKLEY, R. (2000): «La doble transición», en Jordi Gracia, ed., Historia y Crítica de la Literatura Española. Tomo 9: Los nuevos nombres. 1975-2000. Barcelona, Crítica, pp. 68-76.

EsCOHOTADO, A. (2005): Historia general de las drogas, incluyendo el apéndice Fenomenología de las drogas. Madrid, Espasa-Calpe.

GUBERN, R., et alii (1995): Historia del cine español. Madrid, Cátedra.

HAInING, P., ed. (1976): El Club del Haschisch. La droga en la literatura. Madrid, Taurus.

Haro Ibars, E. (2001): Obra Poética. Madrid, Huerga y Fierro.

Iglesia, E. de la (1983): El Pico. España, Ópalo Films.

MERLO, F. (1992): Escatófago (1968-1972). Madrid, Ediciones Libertarias.

Modoro, R. (1984): La transición política. Madrid, Tecnos.

MuRPHY, S. (1990): Le premier Rimbaud ou l'apprentissage de la subversion. Lyon, Presses Universitaires de Lyon.

NúÑEZ, A. (1995): Obra poética (vol. 1). Madrid, Hiperión.

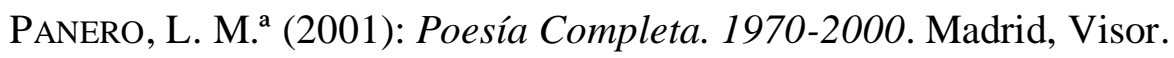

PAZ, O. (2000): Obras Completas. Vol. II: Incursiones / Excursiones. Barcelona, Galaxia Gutenberg / Círculo de Lectores.

PÉREZ-SÁnCHEZ, G. (2007): Queer transition in contemporary Spanish Culture: From Franco to la movida. New York, State University of New York Press.

PraZ, M. (1988): El pacto con la serpiente. México, Fondo de Cultura Económica.

QuincEY, T. de (1930): Confessions of an English Opium Eater, London, J. M. Dent \& Sons.

Rimbaud, A. (1972): Euvres Complètes. París, Gallimard.

- (1995): Poesía completa. Barcelona, Ediciones 29.

RUANO, J. (2012): «La aguja en el tintero. La imagen de las drogas en la poesía española de la transición», en E. RAVENTós-Pons y A. ZAMORA, eds., Aportes recientes a la literature y el arte españoles: Estudios de critica narrativa (Recent Developments in Spanish Literature and Art: Studies in Narrative Criticism). Londres, Edwin Mellen, pp. 97-118.

SUBIRATS, E. (2002): Intransiciones. Crítica de la cultura española. Madrid, Biblioteca Nueva.

Tezanos, J. F.; Cotarelo, R. y Blas, A. de, eds. (1989): La transición democrática española. Madrid: Editorial Sistema.

Tusell, J. (2005): Dictadura Franquista y Democracia. 1939-2004. Historia de España, XIV. Barcelona, Crítica.

VILARÓs, T. M. (1998): El mono del desencanto. Una crítica cultural de la transición española (19731993). Madrid, Siglo XXI.

ZuluetA, I. (1980): Arrebato. España, Nicolás Astiarraga y Augusto Martínez Torres Productores. 